\title{
Gender based Crimes as a Challenge in Women Empowerment in India: An Analysis
}

\author{
Pinki Ninaniya ${ }^{1} *$ and Kapil Singh ${ }^{2}$ \\ ${ }^{1}$ Department of Human Development and Family Studies, COHS, CCS, \\ Haryana Agricultural University, Hisar, Haryana, India \\ ${ }^{2}$ Department of Commerce, Government College, Hisar, Haryana, India \\ *Corresponding author
}

\section{A B S T R A C T}

\begin{tabular}{|l|}
\hline Key w or d s \\
Women safety, \\
Violence, \\
Empowerment, \\
Crime, India \\
\hline Article Info \\
\hline $\begin{array}{l}\text { Accepted: } \\
\text { 10 April } 2019 \\
\text { Available Online: } \\
\text { 10 May } 2019\end{array}$ \\
\hline \hline
\end{tabular}

India is a most famous country for its great traditions and culture where women are given most respected place of 'Goddess Lakshmi' in the society. In India women comprises almost half of the population but still they are fighting for their rights and lag behind in many aspects of life such as education, health, employment etc. in the male dominated society. Worldwide 35 percent women are victim of physical/sexual violence either by husband or relative which is not a good sign for society. India's rank in Gender inequality index is 125 which shows how much we are concern on women related issue and in global gender gap index is 87 even after the flagship program BetiBachao-BetiPadhao. According to a report, India is the world's most dangerous place for women. So we need some most comprehensive and intensive effort to tackle gender based crime. In present paper descriptive research has been used and all the study is based on secondary data. Keeping in above backdrop, the present paper is a humble attempt to understand gender based crimes as a challenge in the way of women empowerment. Present paper also highlights some issues regarding the crime against women in India.

\section{Introduction}

India is a country which is famous all over the world for its great traditions and culture where women are given most respected place of 'Goddess Lakshmi' in the society. From the ancient India women had enjoyed equal status with men in all aspects of lifelike education, marriage etc. except in the medieval period where the status of women declines.In the post medieval period many social reformers fought for the betterment and equality of women in the society. Ram Mohan Roy, Ishwar Chandra Vidyasagar and JyotiRaoPhule fought were some among the list.

In modern India, women are found working in all fields like politics, banks, schools, sports, businesses, army, police, and have held high offices including that of the President, Prime Minister, Speaker of the LokSabha, Leader of 
the Opposition, Union Ministers, Chief Ministers and Governors.India is considered as safer place for women. But Thomson Reuters Foundation (2018) perceived India as the world's most dangerous place for women, citing retrograde cultural practices, sexual violence, and trafficking.

Every year thousands of cases of dowry harassment, assault, kidnapping and rape registered. And in the prevailing surrounding environment thousands of cases are under reported. A recent report reveals that the survivors of sexual assault in India have to face insensitive treatment not only from police but from doctor, lawyers and society also in the whole process of justice. Lack of witness and victim protection laws make girls and women from marginalized communities even more vulnerable to harassment and threats (Human Right Watch, 2019).

No doubt crime against women has increased in last few years i.e. cases of rape cruelty by husband or his relatives were 24206 and 99135 in 2011 and 34651 and 113403 in 2015 even central Government program like BetiBachao, BetiPadhao (save daughters, educate daughters) to make them strengthen in the society.By seeing these types of crimes against women such as rape cases, acid attacks, etc, the safety of women has been in doubt. We need a strong mechanism to deal with gender basis issues.

Female activists also united over issues such as domestic violence, gender biasness, women's health, women's safety, and women's literacy and are doing well in this direction. In the coming sections, we will discuss the review of literature, objectives of the study, present status of women in India, crimes against women in India, measures taken by world's top economies to reduce violence against women and draw conclusions with policy implications.
There are numbers of study which highlight that gender based crimes is a main problem in women's empowerment in India. A few of them are as follows:

Prathiba (2017) have suggested in her study that women empowerment is possible through education, awareness among women of their rights, physical safety and strict implementation of policies and act whereas crime against women like domestic violence, acid throwing, child marriages, dowry, rapes, sexual harassment, honour killing etc. hinder it which further disturb the economic, social and cultural development of a country.

Papita (2014) have conducted study in Bankura district of West Bengal on women Empowerment. According to her women are facing violence not only outside home but within home. Only in west Bengal cases of domestic violence has been reported to increase by $18 \%$ in 2011-12. She concluded that age, education of woman, access to formal credit, highest female education, household landholding, participation in SHG and caste as crucial in the determination of women's empowerment at the community level.

UN Conference on Sustainable Development affirmed that women have central and transformative roles in sustainable economic development of world's economies, and gender equality must be a priority for action in areas including economic, social and political participation and leadership of a country.(UN Women Annual Report, 201213).

Sethuraman et al., (2006) conducted longitudinal observational study in the tribal and rural community of south India. She had tried to develop relationship between women empowerment and domestic violence. She concluded that there is a strong need to reduce 
malnutrition, improving the women nutrition, promoting gender equality, empowering women and reducing the violence against women.

One of the recommendations of the National policy on Education (1986) by the Government of India was to promote "empowerment" of women through the agency of education and it has considered being a landmark in the approach to women's education.

In light of above literature, the present study is a humble attempt to understand that crimes against women are a challenge in the path of women empowerment and their justification.

The following are the main objectives of the present study:-

- To highlight the status of women in our society.

- To analyze the trends in gender based crimes in India.

- To analyze the policies of world's leading countries and Indian Govt. to stop crime against women.

- To analyse whether gender based crimes hinder women's empowerment in India.

\section{Data sources and research methodology}

The present study is based on secondary data which has been taken from various websites, census 2001 and 2011, and reports of Crimes Records Bureau and National Commission for women etc.

Descriptive research design has been used for highlighting the impacts of gender based crimes on women empowerment. The available data has been presented in the form of suitable tables and figures (1-3).

\section{Present status of women in India}

Status of women has changed during different periods. Nowadays, Women are enjoying almost equal status with men in many fields like education, health, economic freedom etc. But still there are some challenges which deprived women to grow faster. Gender based crimes is one of them. Literacy rates, sex ratios, women's participation in labour and crime against women are some development indicators which measures the status of women. So now we are discussing these indicators, literacy rates on of the development indicator has power to change the mind-set of our male dominated society.

Table 1 indicates the literacy rate in India since 1951. In 1951 male literacy rate was 27.2 percent it increases to 80.9 percent in 2011. There is 53.7 percent point increase in male literacy rate. Female literacy rate was just 8.9 percent in 1951 it increases to 64.6 percent in 2011. There is 55.7 percent point increase in female literacy rate. Decadal growth rate in male and female literacy rate is also shown in table 1 . It is clear that growth rate in female literacy rate is higher than male literacy rate.

Now the second development indicator for women status is sex ratio. Everyone in our society wants boy child nobody prefers girl child. In the census of 1981, sex ratio was 934 females per 1000 males. In which further rural contribute 951 and urban areas has 879 females per 1000 females. In comparison to this in 2011, sex ratio was 940 females per 1000 males. If we talk about rural sex ratio in 2011 were 947 females per 1000 boys and 926 per 1000 males in urban areas. This improvement shows nowadays our society is preferring girl child and traditions are changing day by day. Third development indicator for this is participation of women in labour. If we look at figure, which is related 
with the men/ women participation in paid and unpaid work at global level, based on Human Development Report, 2015. Women's participation is less 21 per cent while male contribution is 38 per cent in paid work. In unpaid work women participation 31 per cent and male contribution is 10 per cent. Less participation in paid work is main cause in the declining status of the women.

Last development indicator for this is crime against women. Proportion of crime against women (IPC) towards Total IPC crimes during 2011-2016 were showed in table 2. In 2011 total IPC crime was 23, 25,575 and crime against women 2, 19,142 which was 9.4 percent of total IPC crimes. This proportion shows increasing order up to 2014, 10.2 percent in 2012, 11.2 percent 2013 and 11.4 percent in 2014. Except in the year 2015 cases are increasing at a fast rate which somewhat creating problem in the way of women empowerment.

\section{'*'newly included crime head; '\#' exclude child rapes registered under the section 4 and 6 of protection of children from sexual offences act 2012}

Table 3 clearly shows Crime head wise cases registered under crime against women during 2011-15. Cases of rapes are increasing year by year in this period from 24206 in 2011 to 34651 in 2015 . Whereas cases of attempt to rape has increased from 4232 in 2014 to 4434 in 2015. Cases of kidnapping and abduction of women are increasing at a fast rate. It was 35565, 38262, 51881, 57311, 59277 from 2011-15.

Education among young girls and boys are increasing year to year as a result dowry cases are decreasing in this period 8618 to 7634 . Cases of assault on women with intent to outrage of her/their modesty are almost double during this period which is 42968 to 82422. Insult to the modesty of women shows increasing trend in 2011, 12 and 13 and decreasing trend in $2014 \& 15$. There are growing trends in cases of cruelty by husband or his relatives as shown in the table 4. Due to strict implementation of law and policies cases of importation of girls from foreign country is low to 06 in 2015 as compare to 80 in 2011. There is a fast growth in Abetment of suicide of women cases in 2015 of 4060 as compare to 3734 in 2014. If we talk about total IPC crimes against women, there is tremendous growth of $40 \%$ during the period which is not a good sign.

Cases registered under commission of sati prevention act are nil whereas decreasing trends is in indecent representation of women act from 453 in 2011 to 40 in 2015. Cases registered in the dowry prevention act was 6619 in 2011 and 9038, 10709, 10050 and 9894 in 2012, 13, 14 and 15 respectively. Cases in Protection of women from domestic violence act was 426 in 2014 whereas 461 in 2015. Cases in immoral traffic (Prevention) act are depicting mix trends during 2011-15. During this period total SLL crime against women was 9508 in 2011 and 12819 in 2015 it is about $35 \%$ more than cases in 2011 .

Total cases during the same period has increased $43 \%$ which shows that women are facing much problems very from birth to young and in old age also. Analysis of above table 5 depicts that the highest complaint received from Uttar Pradesh (9756), Delhi (1830), Haryana (994), Rajasthan (696) and Bihar (572). Instead having good sex ratio and literacy rates these states are facing much problem in the way of women empowerment. These numbers should be nil in all the states as soon as possible. Whereas north-east states are establishing milestone and case registered are in Arunachal Pradesh (1), Manipur (1), Mizoram (1), Nagaland (1), Sikkim (3) and Tripura (1). 
Measures taken by other countries to reduce the violence against women and girls

\section{United States of America}

1. Begin work to reduce domestic violence in up to 12 communities of US.

2. Establishment of National Sexual Assault Forensic Medical Examination Telemedicine Centre in U.S. to improve quality evidence collection.

3. Assess family court structures and processes in domestic violence cases.

4. Work with local police agencies to develop model performance measures, internal guidelines, and quality assurance mechanisms.

5. To continue implementation of the United States National Action Plan on Women, Peace and Security and the United States Strategy to prevent and Respond to Gender-based Violence Globally.

\section{United Kingdom}

1. The United Kingdom commits to continue its efforts to end all forms of violence against women and girls and for it GBP $£ 40$ million as stable funding provided by govt. for specialist services.

2. Piloted new ways of protecting victims of domestic violence; and launched national prevention campaigns to tackle rape and relationship abuse and is planning to criminalize forced marriage.

3. The UK has also published an updated action plan on 8 March and has vowed to do more to support the most underrepresented and vulnerable women and girls.

4. The Government has further supported the devolution of power to local decision-makers, who are best-placed to commission and provide services to victims.
5. In relation to its devolved administrations, the Welsh Government has in place a six-year integrated strategy 'Right to be Safe' for tackling violence against women and domestic abuse.

\section{Russian Federation}

1. Comprehensive measures are being taken include public information campaigns and social rehabilitation work.

2. Through social services, Russia is focusing on the prevention of domestic abuse and the provision of services to survivors.

3. Specialist support in crisis situations is provided by crisis centres for women, and for men. They offer psychological, legal, medical, teaching and welfare services to various categories of women who have suffered violence and to men and boys who have suffered violence. Nongovernment organizations play an active part in providing social services to women affected by domestic violence.

4. Among the most recent measures, as part of the plan to implement the recommendations of the Committee to Eliminate Discrimination against Women (CEDAW), a working group has been set up to draw up a draft federal law, "On the prevention of domestic violence".

5. A National Crisis Centre Network has been established, embracing state and civic crisis centres, set up by women's organizations;

6. National helpline for domestic abuse survivors has been launched;

7. A course of training workshops and optional classes has been held for students at the

8. Moscow police colleges and for police commissioners at the Russian Institute of Advanced Training for Interior Ministry Personnel; 
Table.1 Literacy rate in India and its decadal growth (in percentage)

\begin{tabular}{|c|c|c|c|c|}
\hline Year & Males & Females & $\begin{array}{c}\text { \% Age growth rate in } \\
\text { male literacy rate }\end{array}$ & $\begin{array}{c}\text { \% age growth rate IN } \\
\text { female literacy rate }\end{array}$ \\
\hline $\mathbf{1 9 5 1}$ & 27.2 & 8.9 & ----- & ------ \\
\hline $\mathbf{1 9 6 1}$ & 40.4 & 15.4 & 48.53 & 73.034 \\
\hline $\mathbf{1 9 7 1}$ & 46 & 22 & 13.86 & 42.857 \\
\hline $\mathbf{1 9 8 1}$ & 56.4 & 29.8 & 22.61 & 35.455 \\
\hline $\mathbf{1 9 9 1}$ & 64.1 & 39.3 & 13.65 & 31.879 \\
\hline $\mathbf{2 0 0 1}$ & 75.3 & 53.7 & 17.47 & 36.641 \\
\hline $\mathbf{2 0 1 1}$ & 80.9 & 64.6 & 7.437 & 20.298 \\
\hline
\end{tabular}

Source: Census of India 2011

Table.2 Proportion of Crime against Women (IPC) towards Total IPC Crimes

\begin{tabular}{|c|c|c|c|c|}
\hline Sr. no. & Year & Total IPC Crimes & $\begin{array}{c}\text { Crime against Women } \\
\text { (IPC cases) }\end{array}$ & $\begin{array}{c}\text { Percentage to total } \\
\text { IPC Crimes }\end{array}$ \\
\hline 1 & 2011 & $23,25,575$ & $2,19,142$ & $9.4 \%$ \\
\hline 2 & 2012 & $23,87,188$ & $2,44,270$ & $10.2 \%$ \\
\hline 3 & 2013 & $26,47,722$ & $2,95,896$ & $11.2 \%$ \\
\hline 4 & 2014 & $28,51,563$ & $3,25,327$ & $11.4 \%$ \\
\hline 5 & 2015 & $29,49,400$ & $3,14,575$ & $10.7 \%$ \\
\hline 6 & 2016 & $29,75,711$ & $3,25,652$ & $10.9 \%$ \\
\hline
\end{tabular}

Source: National Crime Records Bureau, GOI, 2016

Table.3 Crime head wise cases registered under crime against women during 2011-15

\begin{tabular}{|c|c|c|c|c|c|c|}
\hline \multirow{2}{*}{$\begin{array}{l}\text { Sr. } \\
\text { no. }\end{array}$} & \multirow[t]{2}{*}{ Crime head } & \multicolumn{5}{|c|}{ Year } \\
\hline & & 2011 & 2012 & 2013 & 2014 & 2015 \\
\hline 1 & Rape\# & 24,206 & 24,923 & 33,707 & 36,735 & 34,651 \\
\hline 2 & Attempt to commit rape* & - & - & - & 4,232 & 4,434 \\
\hline 3 & Kidnapping and Abduction of women & 35,565 & 38,262 & 51,881 & 57,311 & 59,277 \\
\hline 4 & Dowry deaths & 8,618 & 8,233 & 8,083 & 8,455 & 7,634 \\
\hline 5 & $\begin{array}{l}\text { Assault on women with intent to outrage of her/their } \\
\text { modesty }\end{array}$ & 42,968 & 45,351 & 70,739 & 82,235 & 82,422 \\
\hline 6 & Insult to the modesty of women & 8,570 & 9,173 & 12,589 & 9,735 & 8,685 \\
\hline 7 & Cruelty by husband or his relatives & 99,135 & $1,06,527$ & $1,18,866$ & $1,22,877$ & $1,13,403$ \\
\hline 8 & Importation of girl from foreign country & 80 & 59 & 31 & 13 & 06 \\
\hline 9 & Abetment of Suicide of women & - & - & - & 3,734 & 4,060 \\
\hline A. & Total IPC crimes against women & $2,19,142$ & $2,32,528$ & $2,95,896$ & $3,25,327$ & $3,14,575$ \\
\hline 10 & Commission of sati prevention act & 0 & 0 & 0 & 0 & 0 \\
\hline 11 & Indecent representation of women act & 453 & 141 & 362 & 47 & 40 \\
\hline 12 & The dowry Prevention act & 6,619 & 9,038 & 10,709 & 10,050 & 9,894 \\
\hline 13 & Protection of women from domestic violence act & - & - & - & 426 & 461 \\
\hline 14 & Immoral traffic (Prevention) act & 2,436 & 2,563 & 2,579 & $2,070 \#$ & 2,424 \\
\hline B. & Total SLL crime against women & 9,508 & 11,742 & 13,650 & 12,593 & 12,819 \\
\hline & Total $(A+B)$ & $2,28,650$ & $2,44,270$ & $3,09,546$ & $3,37,922$ & $3,27,394$ \\
\hline
\end{tabular}

Source: National Crime Records Bureau, GOI 
Table.4 Category-wise list of complaints received during 2016-2017

\begin{tabular}{|c|l|c|}
\hline Sr. no. & Nature of Complaint received & Total \\
\hline $\mathbf{1}$ & Bigamy / Polygamy & 163 \\
\hline $\mathbf{2}$ & Cyber Crime against women & 325 \\
\hline $\mathbf{3}$ & Dowry harassment / dowry death & 2255 \\
\hline $\mathbf{4}$ & Free legal aid for women & 185 \\
\hline $\mathbf{5}$ & Gender Discrimination including equal right to education and work & 60 \\
\hline $\mathbf{6}$ & Indecent Representation of Women & 120 \\
\hline $\mathbf{7}$ & Outraging Modesty of Women & 1125 \\
\hline $\mathbf{8}$ & Police Apathy against women & 4710 \\
\hline $\mathbf{9}$ & Privacy of women and rights thereof & 148 \\
\hline $\mathbf{1 0}$ & Reproductive health rights of women & 91 \\
\hline $\mathbf{1 1}$ & Right to Exercise Choice in marriage & 434 \\
\hline $\mathbf{1 2}$ & Right to live with dignity & 5504 \\
\hline $\mathbf{1 3}$ & Sex selective abortion / female foeticide / amniocentesis & 38 \\
\hline $\mathbf{1 4}$ & Sexual harassment including sexual harassment at workplace & 522 \\
\hline $\mathbf{1 5}$ & Stalking / Voyeurism & 130 \\
\hline $\mathbf{1 6}$ & Traditional practices derogatory to women rights i.e. sati pratha, devdasipratha, & 13 \\
\hline & witch hunting & 124 \\
\hline $\mathbf{1 7}$ & Trafficking / Prostitution of women & 1293 \\
\hline $\mathbf{1 8}$ & Violence against women & 50 \\
\hline $\mathbf{1 9}$ & Women's right of custody of children in the event of divorce & $\mathbf{1 7 2 9 0}$ \\
\hline & & Total \\
\hline
\end{tabular}

Source: Annual report of National commission for women 2016-17

Table.5 State-wise list of complaints received during 2016-2017

\begin{tabular}{|c|c|c|c|c|c|}
\hline Sr. no. & State/Union Territory & Total & Sr. no. & State/Union Territory & Total \\
\hline $\mathbf{1}$ & Andaman and Nicobar Islands & 2 & 19 & Lakshadweep & 1 \\
\hline $\mathbf{2}$ & Andhra Pradesh & 107 & 20 & Madhya Pradesh & 498 \\
\hline $\mathbf{3}$ & Arunachal Pradesh & 1 & 21 & Maharashtra & 569 \\
\hline $\mathbf{4}$ & Assam & 41 & 22 & Manipur & 1 \\
\hline $\mathbf{5}$ & Bihar & 572 & 23 & Mizoram & 1 \\
\hline $\mathbf{6}$ & Chandigarh & 42 & 24 & Nagaland & 1 \\
\hline $\mathbf{7}$ & Chhattisgarh & 74 & 25 & Odisha & 107 \\
\hline $\mathbf{8}$ & Dadra and Nagar Haveli & 4 & 26 & Pondicherry & 18 \\
\hline $\mathbf{9}$ & Daman and Diu & 1 & 27 & Punjab & 283 \\
\hline $\mathbf{1 0}$ & Delhi & 1830 & 28 & Rajasthan & 696 \\
\hline $\mathbf{1 1}$ & Goa & 5 & 29 & Sikkim & 3 \\
\hline $\mathbf{1 2}$ & Gujarat & 994 & 30 & Tamil Nadu & 334 \\
\hline $\mathbf{1 3}$ & Haryana & 31 & 32 & Telangana & 127 \\
\hline $\mathbf{1 4}$ & Himachal Pradesh & 35 & 33 & Tripura & 1 \\
\hline $\mathbf{1 5}$ & Jammu and Kashmir & 186 & 34 & Uttar Pradesh & 9756 \\
\hline $\mathbf{1 6}$ & Jharkhand & 256 & 35 & West Bengal & 258 \\
\hline $\mathbf{1 7}$ & Karnataka & 110 & & Total & $\mathbf{1 7 2 9 0}$ \\
\hline $\mathbf{1 8}$ & Kerala & & & 237 \\
\hline
\end{tabular}

Source: Annual report of National commission for women 2016-17. 
Fig.1 Sex Ratio in India (1981- 2011)

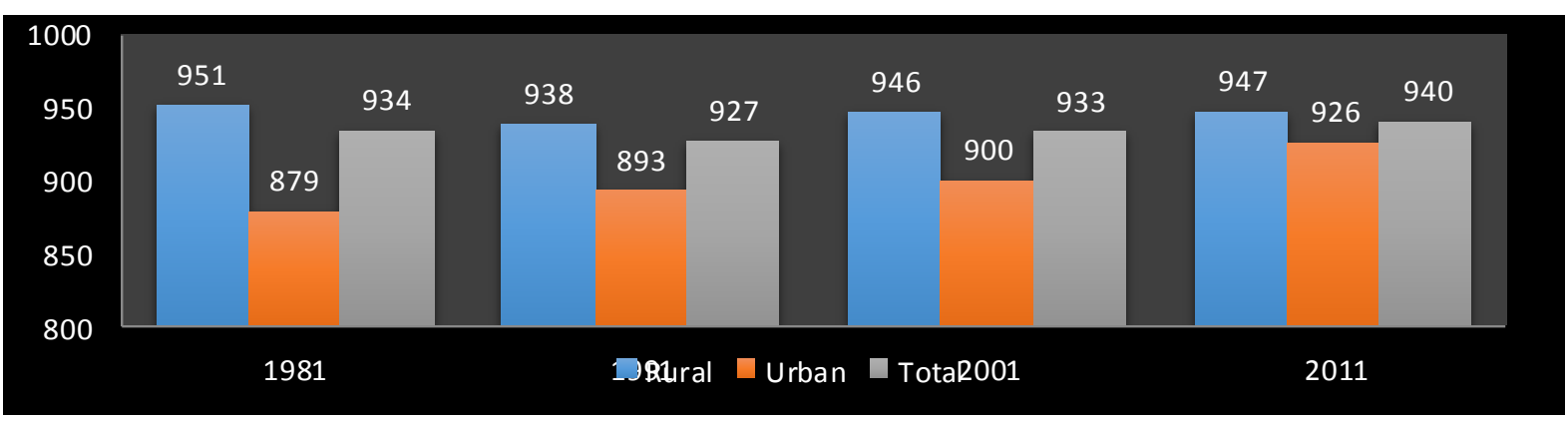

Source: Census of India 2011

Fig.2 Global share of men and women in Paid/Unpaid Work (in \%)

Source: Human Development Report, 2015

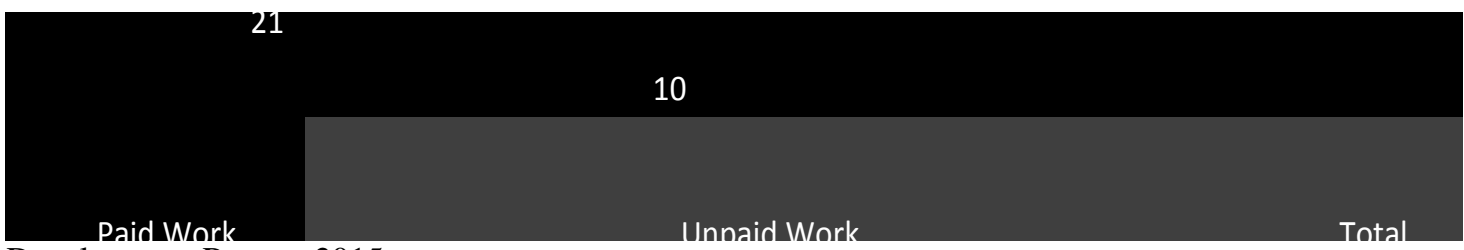

Fig.3 Diagrammatic representation of category-wise list of complaints received (2016-2017)

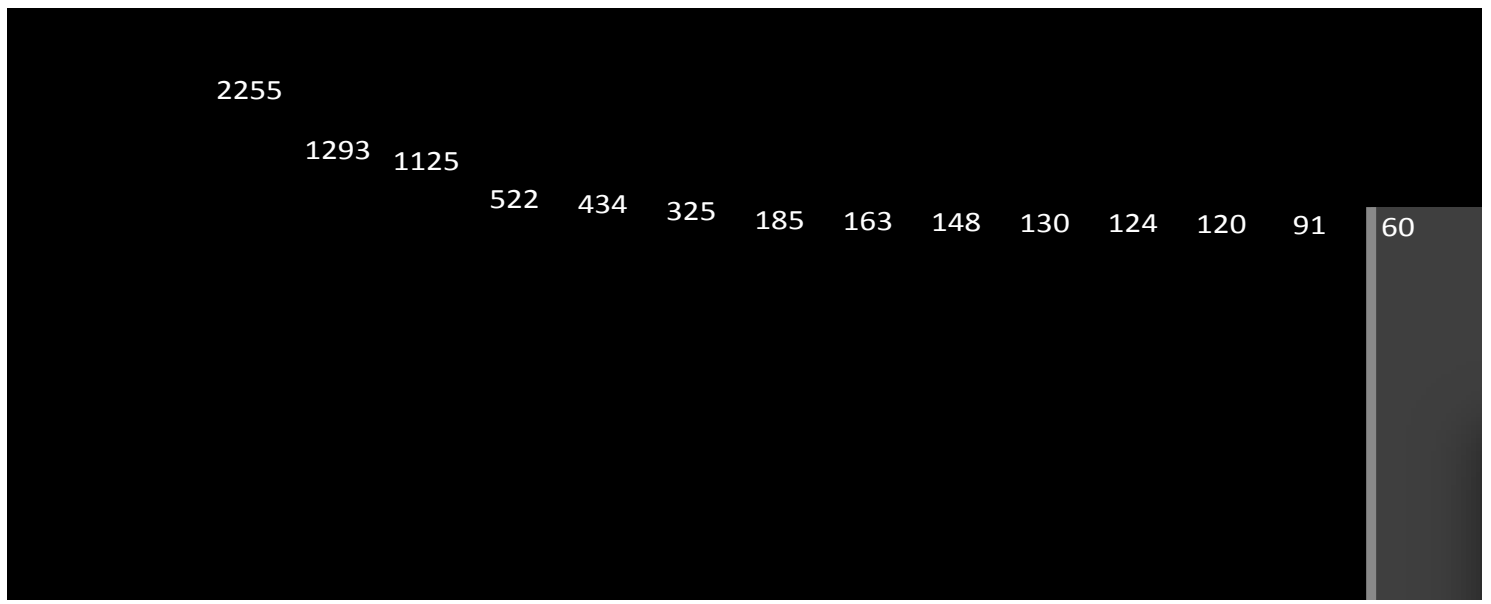

Source: Annual report of National commission for women 2016-17

Note: This does not include Miscellaneous/Non Mandate categories of complaints.

Analysis of above table and figure reveals that total no. of complaints received by Complaints and Investigation Cell during 2016-17 was 17290 in which highest complaints received concerns with right to live with dignity followed by police apathy against women, dowry harassment/ dowry deaths and violence against women. 


\section{Australia}

1. Public campaign and educational projects in educational institutes to prevent sexual assault and domestic violence.

2. Community Action Grants to reduce violence against women, and zero tolerance programs in local clubs.

3. For the safe working environment for women The White Ribbon Workplaces Project started.

4. New telephone and Online counselling service on: www.1800RESPECT.org.au.

5. Through another program, DV-alert, for health, allied health and Indigenous health workers will be trained to recognize and respond to domestic violence.

6. A National Centre of Excellence has been set up to facilitate and coordinate research activity into domestic and family violence and sexual assault.

Analysis of above measures taken by other countries it is clear that world's top most economies are following zero tolerance policy in gender based crimes.

\section{Some initiatives by Indian govt. to reduce} the violence against women and girls

1. For the empowerment of women and reducing gender base crimes govt. of India allotted a fund of Rs. 124670.89 crores as per revised estimate of 2018-19 and Rs. 131699.52 crores as per budget estimate of 2019-20 in Gender budget.

2. To facilitate women affected by violence and to provide them medical assistance, police assistance, psycho-social support, legal aid and counselling, temporary shelter and video conferencing to facilitate Police and Court proceedings there is proposal of setting up one stop centre in 660 locations in country (2015).

3. Women Helpline, which is sought to be universalized, would be a toll free service accessible to women in distress anywhere, anytime in the country through a single universal number (181).

4. In Code of Criminal Procedure 1973 through the Code of Criminal Procedure (Amendment) Act, 2008 new provision regarding compensation to victims of crime has been inserted.

5. A web Portal on Anti Human Trafficking was developed by Ministry of Home Affairs and launched in 2014 for effective implementation of Anti-Human trafficking measures to enhance cooperation between law enforcement agencies, and concerned government departments as well.

6. Nirbhaya Fund has been set up to support initiatives towards protecting the dignity and ensuring safety of women in India with a total cost Rs. 3216.9 million.

7. To prevent violence against women some amendment has been made in IPC, CCP\&IEA regarding offences like acid attack, sexual harassment, voyeurism, disrobing a woman, stalking, rape, indecent gestures like words, physical exploitation or any form of sexual exploitation, slavery, servitude, or the forced removal of organs and inappropriate touch.

8. Protection of Children from Sexual Offences Act 2012 provides protection to children, from the offences of sexual assault, sexual harassment and pornography. The Act incorporates childfriendly procedures for reporting, recording of offences, investigation and trial of offences.

These are few measures to prevent physical/sexual violence against women, girls and children in India.

There are so many other measures in this regard, it are not the end of list. 


\section{Conclusions with policy implications}

In brief, we can say that women are the second wheel of the society which bears much responsibility not only of family but also of working formal and informal organizations, still they are lag behind in literacy, health facilities, economic freedom\& participation in labour and facing physical/sexual violence not the outside home but inside the home by her husband and relatives. Recent statistics shows that crimes against women has increased in last few years mostly in high literacy rates states like UP, Delhi and Haryana instead having good govt. initiatives.

Analysis of development indicator like literacy rate, sex ratio, participation in labour and gender based crime shows that status of women have improved and women are working shoulder to shoulder with men in recent years all over country. Developed countries like USA, UK, Australia, Russia etc. are following zero tolerance policy for crime against women and girls. Though Indian govt. had taken the initiative in the form of One-Stop centre, changes in criminal Acts/law, Web portal for Anti-Human Trafficking, women helpline, Gender Budgeting etc. yet there is a strong need to take some sincere, comprehensive and intensive effort for removing the gender inequality and reducing the gender based crime. Otherwise gender based crime will be a main challenge in the way of women empowerment. Gender budgeting can be a powerful tool for women empowerment by reducing this inequalities prevailing in our society through proper resource allocation. Last but not least, if we truly want to reduce gender based crimes and inequality then we must start this from our own home, then we can think about empowered women and sustainable economic development of the country and the world.

\section{References}

http://evaw-globaldatabase.unwomen.org/en/countries/asia /india

http://news.trust.org/item/20180612134519cxz54/

http://shodhganga.inflibnet.ac.in/bitstream/10 603/56905/1/papita\%20dutta\%20ph.d. $\%$ 20thesis.pdf

http://www.unwomen.org/en/what-wedo/ending-violence-againstwomen/takeaction/commit/governmentcommitments

https://www.hrw.org/worldreport/2019/countrychapters/india\#e 81181

Human Right Watch, 2019

National Commission for Women, 2016-17, PP5-12.

National Crime Records Bureau, GOI, 2016.

Ninaniya P. and Singh K. (2018). Population Growth and Its Possible Effects on Indian Economy Remarking An Analisation, Volume 3, Issue 3, PP 7678.

Pratibha L. (2017). A Study on Issues and Challenges of Women Empowerment In India Global Journal for Research Analysis, Volume 6, Issue 9, PP 138140.

Sethuraman K. et al., (2006). Women Empowerment and Domestic Violence: The Role of Sociocultural Determinants in Maternal and Child Undernutrition in Tribal and Rural Communities in South India Food and Nutrition Bulletin, vol. 27, no.2, PP 128-143.

Shettar M. Rajeshwary (2015). A Study on Issues and Challenges of Women Empowerment In India IOSR Journal of Business and Management, Volume 17, Issue 4, PP. 13-19.

Singh K. (2016). Women Empowerment through Gender Budgeting In India 
Global Journal for Research Analysis, Volume 5, Issue 7, PP 199-202.

Thomas Reuters Foundation, 2018

UN Women Annual Report 2012-13.
Retrieved from UN Women website: www.unwomen.org/media/publications Union Budget 2019-20, expenditure profile, part -I, Gender Budget Statement.

\section{How to cite this article:}

Pinki Ninaniya and Kapil Singh. 2019. Gender based Crimes as a Challenge in Women Empowerment in India: An Analysis. Int.J.Curr.Microbiol.App.Sci. 8(05): 743-753. doi: https://doi.org/10.20546/ijcmas.2019.805.087 